\title{
BEACH MORPHOLOGIES AT NOTSUKEZAKI SAND SPIT, JAPAN
}

\author{
Kentaro Hayashi ${ }^{1}$, Koji Hashimoto ${ }^{2}$, Kazuki Yagisawa ${ }^{2}$, and Nobuhisa Kobayashi ${ }^{3}$
}

\begin{abstract}
Notsukezaki Sand Spit is the longest sand spit in Japan and the wave and morphological characteristics vary along the spit. The main purpose of this study is to investigate the morphological changes of the sand spit for long-term and mid-term field observations and aerial photos. The natural and morphological characteristics are investigated based on the field observations and aerial photos for a long-term period (decades). The regional sediment budget is estimated using the shoreline changes and the result of wave hindcast simulation for five years. Finally, the cross-shore beach processes are examined using the numerical model, CSHORE.
\end{abstract}

Keywords: sand spit, regional sediment budget, cross-shore beach process

\section{Introduction}

A sand spit is a deposition landform along coasts, caused mainly by dominant littoral drift and wave action. There are few sand spits in Japan and the spits are eroding now. The main reasons are the influence of construction of coastal structures (i.e., ports) and the decrease of sand supply from rivers. Those erosion problems have become critical in Japan.

There were several researchers studying the morphology of sand spits. Among them, Johnson (1919) reported the developing processes of Sandy Hook, NJ and King and McCullagh (1971) established a simulation model based on a Monte Carlo method in terms of different directional wave effects to predict the sand spit formation.

Notsukezaki Sand Spit is the largest sand spit in Japan, which is located in the eastern Hokkaido. Its erosion problem has persisted since 1960s and several measures of coastal protection have been constructed. The main purpose of this study is to investigate the natural and morphological characteristics based on field observations and aerial photos for a long-term period (decades). The regional sediment budget is estimated using the shoreline changes. Finally, the cross-shore beach processes are examined using the numerical model, CSHORE (Kobayashi et al. 2008).

\section{Study Area}

Notsukezaki Sand Spit has a beautiful shape like a hook and is the largest sand spit in Japan, which is located in the eastern Hokkaido, Japan. As shown in Figure 1, it faces the Nemuro Strait and is surrounded by Shiretoko Peninsula on the north side, Kunashiri Island on the east side and Nemuro Peninsula on the south side. Therefore, the wave climate can change significantly along the sand spit. The length of the sand spit is about $26 \mathrm{~km}$ from the Shibestu fishing port. Every winter, drift ice floating from the Ohktsuk Sea covers the Nemuro Strait. The tidal range is $1.6 \mathrm{~m}$.

Uda and Yamamoto (1992) reported that the sand spit had been formed by the large amount of longshore sediment transport supplied by rivers and cliff erosion. They analyzed the wave characteristics and the horizontal and vertical sediment characteristics of boring surveys at 5 points along the sand spit to infer the origin of the spit.

Since 1960, the beach erosion problem has become severe. The construction of Shibetsu port updrift of the sand spit intercepted the longshore sediment transport and the large volume of sediment has been deposited and dredged every year. The volume has reached about $20,000 \mathrm{~m}^{3} / \mathrm{yr}$ recently. The narrowest part of the sand pit which is about $50 \mathrm{~m}$ wide, might be breached during a storm. In order to reduce the erosion and protect the fishery houses built on the sand spit, many coastal structures, such as groins and wave absorbing breakwaters, were constructed and beach nourishment has recently been carried out as an effective countermeasure. The beach erosion, however, has not stopped.

\footnotetext{
${ }^{1}$ Engineering Division, Alpha Hydraulic Engineering Consultants Co., Ltd. Tokyo Branch, 2-7-9 Higashikanda Chiyoda-ku, Tokyo, 101-0031, Japan

2 Engineering Division, Alpha Hydraulic Engineering Consultants Co., Ltd., 9-14 Hassamu Nishi-ku, Sapporo, Hokkaido, 063-0829, Japan

${ }^{3}$ CACR, University of Delaware, Newark, DE, 19716, USA
} 


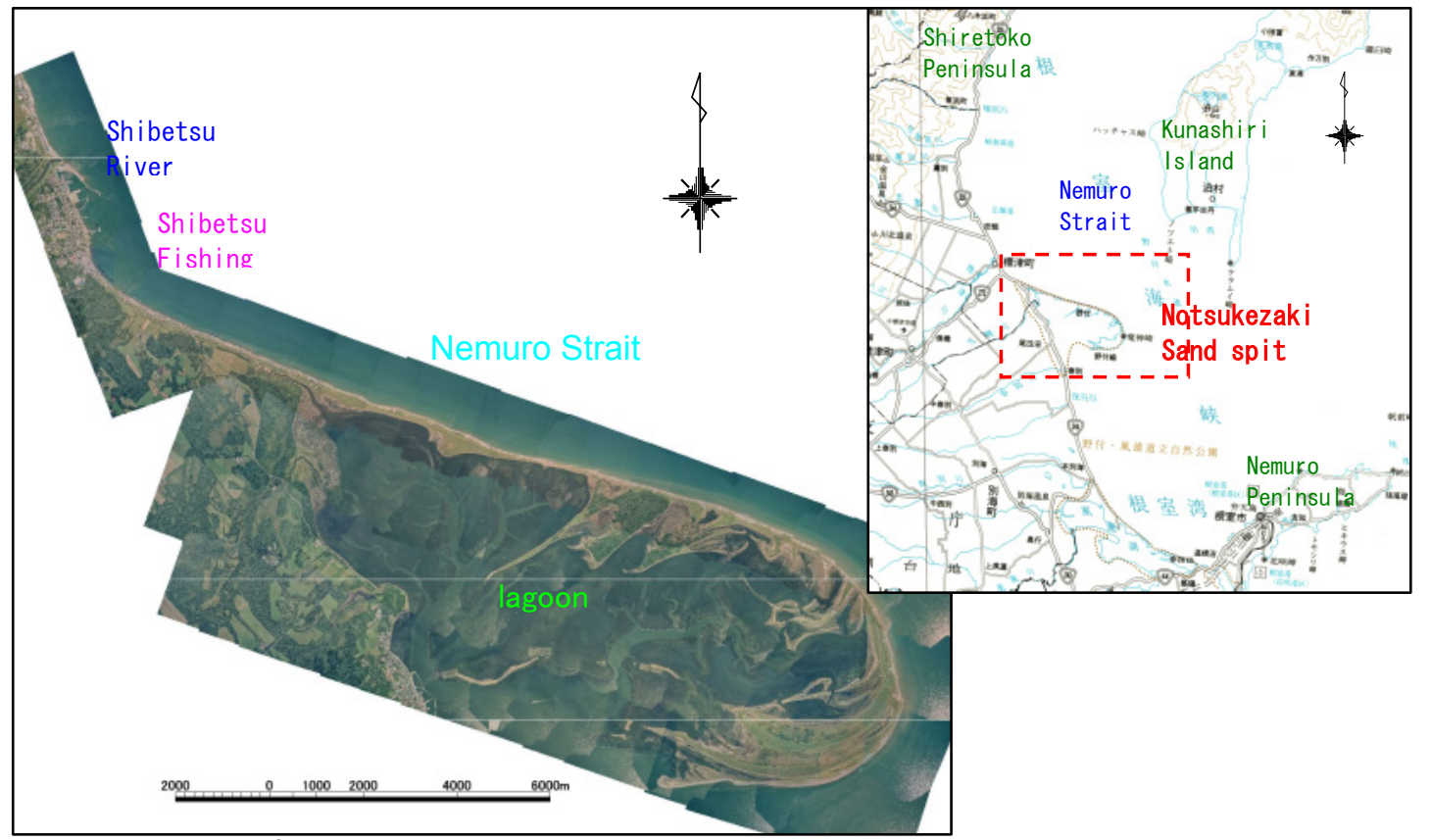

Figure 1. Location of study site.

\section{Field Observations}

\section{Wave Observation}

There is no long-term wave observation station along the coast. In this study, we measured waves at the representative locations of St. 1 and St.2 in winter 2003 to quantify the wave conditions along the Notsukezaki sand spit. St.1 was $11.7 \mathrm{~m}$ deep and St.2 was $9.7 \mathrm{~m}$ deep. Figure 2 summarizes the locations and the directional distributions of the observed significant wave heights. During this observation, the maximum significant wave height at St.1 was $2.86 \mathrm{~m}$, the corresponding wave period was $14.2 \mathrm{~s}$ and the dominant wave direction was NW. On the other hand, at St.2 the significant wave height at the same time was $0.88 \mathrm{~m}$ and the wave period was $6.5 \mathrm{~s}$. As shown in Figure 2, the dominant wave direction is NW at both stations. At St1, about $80 \%$ waves came from NW, NNW, and N. The dominant wave direction at St2 was NW as well; however, $40 \%$ waves came from the eastern directions (NE - ESE). The wave height was relatively small at St, 2. This is because the offshore Kunashiri Island blocks the waves from northern directions.

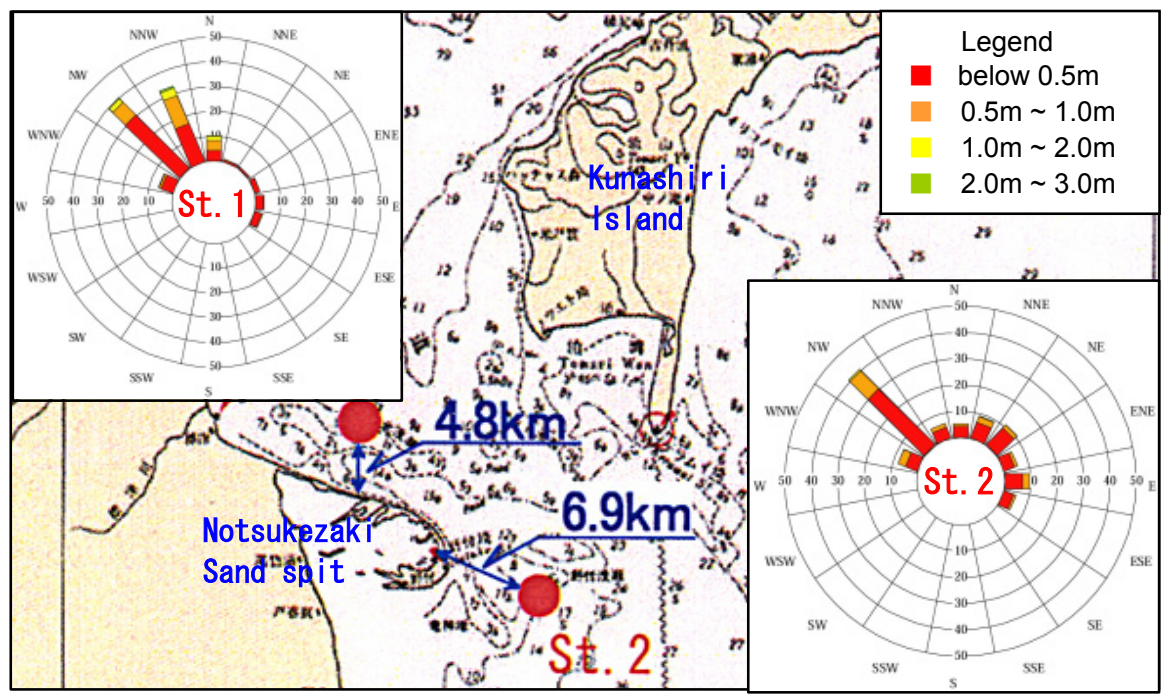

Figure 2. Location of wave observation and measured wave heights and directions. 
Figures 3 and 4 show the relationships between the wave heights and wave directions at St.1 and St.2. For the waves from NW, the larger wave height occurred at St. 1. On the other hands, the waves from E were larger at St.2. The wave direction was not correlated much between St.1 and St.2. Therefore, the Notsukezaki sand spit has the different wave conditions along the spit.

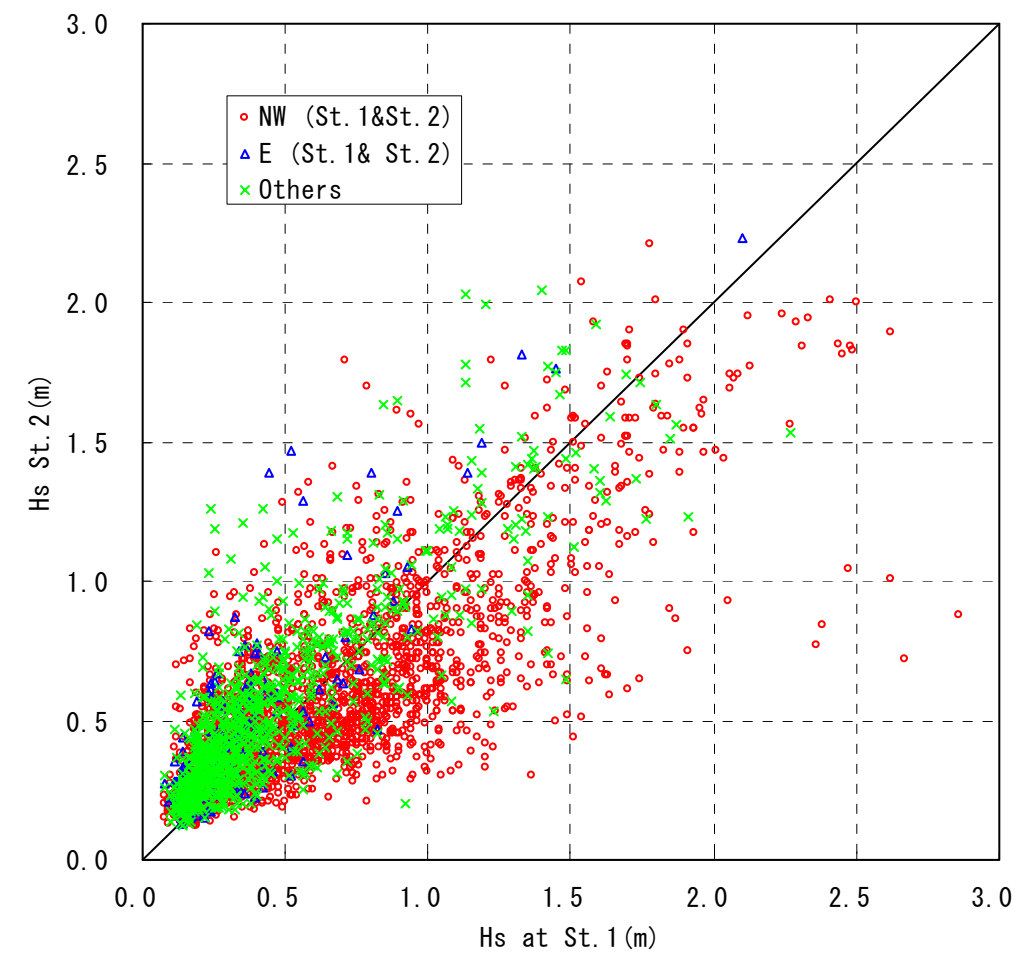

Figure 3. Relationship between significant wave heights at St.1 and St.2.

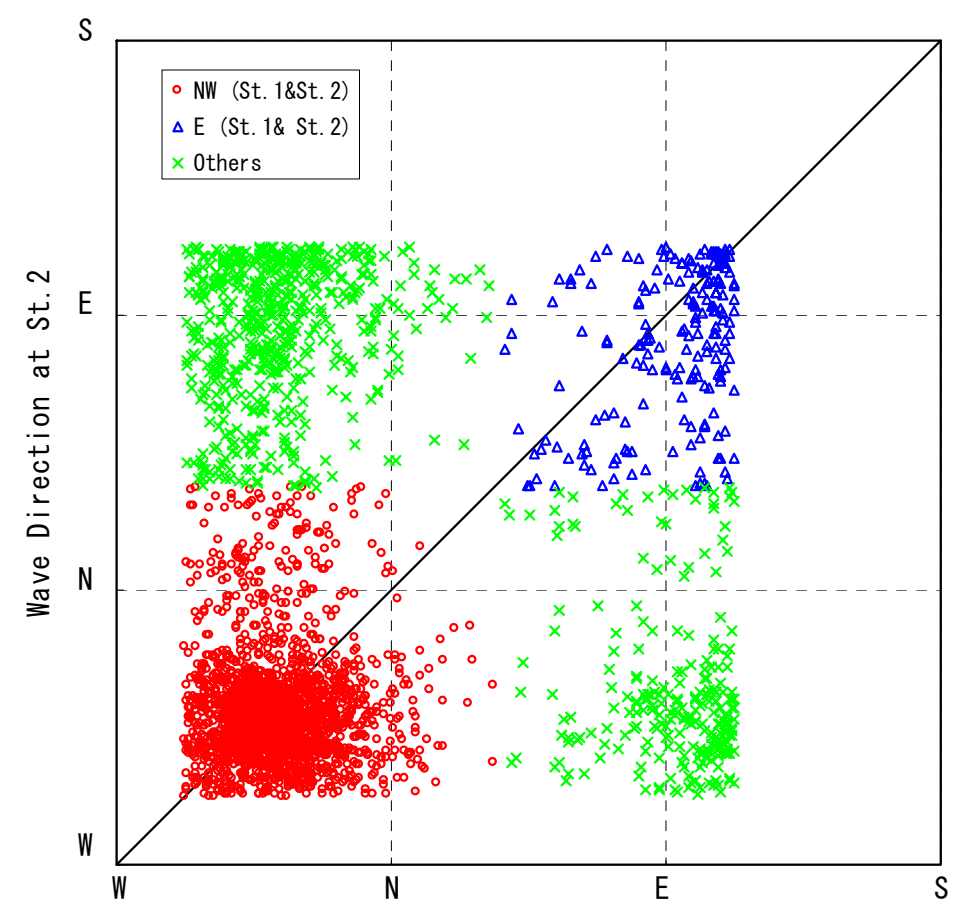

Wave Direction at St. 1

Figure 4. Relationship between wave directions at St.1 and St.2. 


\section{Bathymetric and Shoreline Survey}

Since 1992, several bathymetric surveys have been conducted at representative cross sections along the sand spit. In this study, 12 profiles were selected to investigate the morphological characteristics. Figure 5 shows the locations of the observed profiles along the sand spit and Table 1 summarizes the survey years where profiles No. 11 and No. 12 were not surveyed in 1992. Since 2005, shoreline survey has been conducted by walking along shoreline with Real-Time Kinematic Global Positioning System (RTK-GPS) every year in order to obtain more detailed shoreline position. The survey results are analyzed to obtain the morphological changes in the following.

\begin{tabular}{|c|c|c|c|c|c|c|}
\hline \multicolumn{7}{|c|}{ Table 1.History of bathymetric surveys. } \\
\hline Section & Profile & 1992 & 1999 & 2003 & 2004 & 2007 \\
\hline \multirow{4}{*}{ A } & No.1 & $\bigcirc$ & $\bigcirc$ & $\bigcirc$ & $\bigcirc$ & $\bigcirc$ \\
\cline { 2 - 7 } & No.2 & $\bigcirc$ & $\bigcirc$ & $\bigcirc$ & $\bigcirc$ & $\bigcirc$ \\
\cline { 2 - 7 } & No.3 & $\bigcirc$ & $\bigcirc$ & $\bigcirc$ & $\bigcirc$ & $\bigcirc$ \\
\cline { 2 - 7 } & No.4 & $\bigcirc$ & $\bigcirc$ & $\bigcirc$ & $\bigcirc$ & $\bigcirc$ \\
\cline { 2 - 7 } & No.11 & - & $\bigcirc$ & $\bigcirc$ & $\bigcirc$ & $\bigcirc$ \\
\cline { 2 - 7 } & No.5 & $\bigcirc$ & $\bigcirc$ & $\bigcirc$ & $\bigcirc$ & $\bigcirc$ \\
\hline \multirow{4}{*}{ B } & No.12 & - & $\bigcirc$ & $\bigcirc$ & $\bigcirc$ & $\bigcirc$ \\
\cline { 2 - 7 } & No.6 & $\bigcirc$ & $\bigcirc$ & $\bigcirc$ & $\bigcirc$ & $\bigcirc$ \\
\hline \multirow{4}{*}{ C } & No.7 & $\bigcirc$ & $\bigcirc$ & $\bigcirc$ & $\bigcirc$ & $\bigcirc$ \\
\cline { 2 - 7 } & No.8 & $\bigcirc$ & $\bigcirc$ & $\bigcirc$ & $\bigcirc$ & $\bigcirc$ \\
\cline { 2 - 7 } & No.9 & $\bigcirc$ & $\bigcirc$ & $\bigcirc$ & $\bigcirc$ & $\bigcirc$ \\
\cline { 2 - 7 } & No.10 & $\bigcirc$ & $\bigcirc$ & $\bigcirc$ & $\bigcirc$ & $\bigcirc$ \\
\hline
\end{tabular}

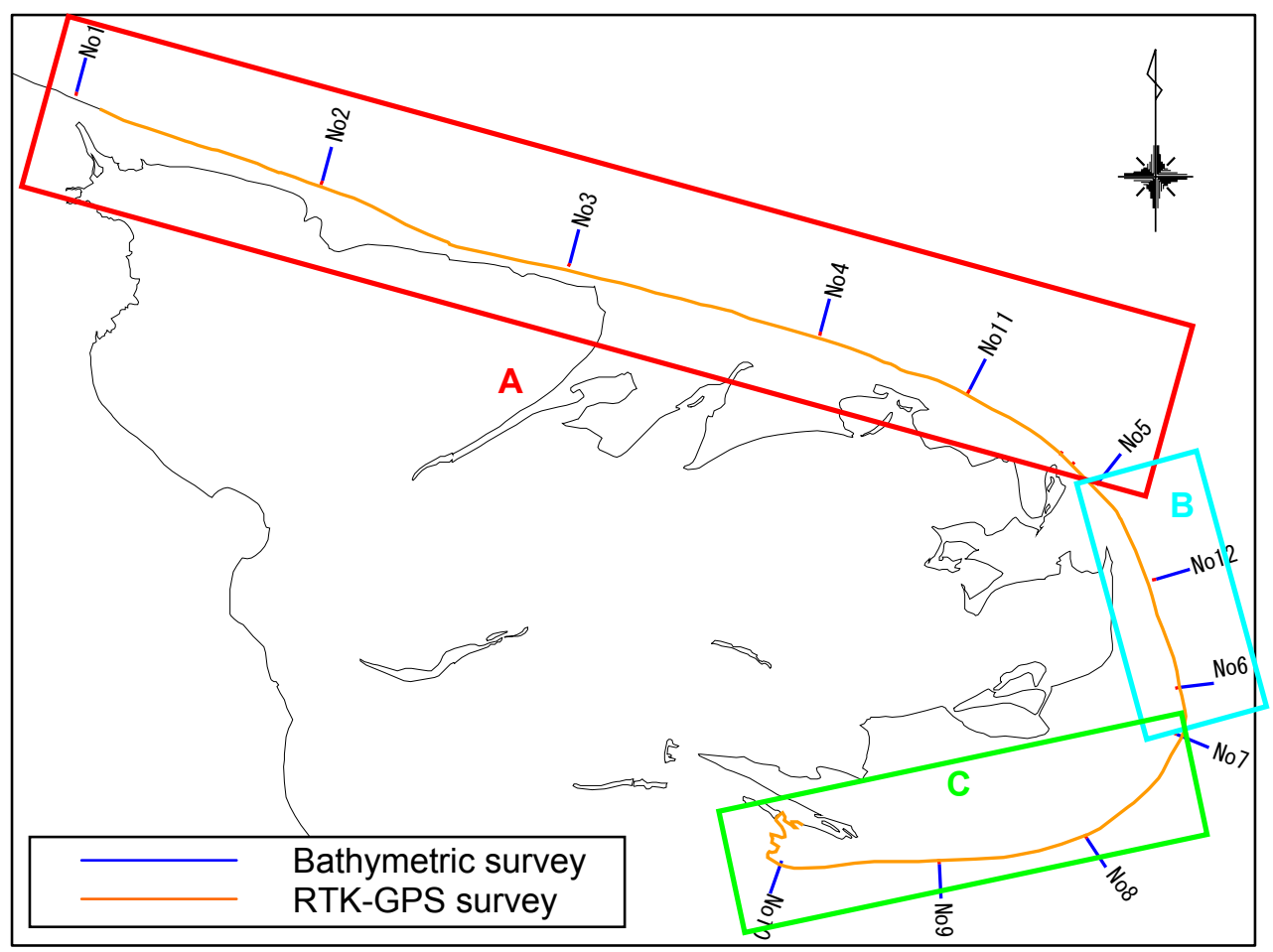

Figure 5. Location of bathymetric surveys and RTK-GPS shoreline survey. 


\section{Sediment Samplings}

In 1999, a sediment sampling survey was conducted at the 12 profiles. Sediment samples were collected from the shoreline and 1-m depth positions. Figure 6 shows the location and the median grain size at the shoreline position (yellow number) and the 1-m depth position (black number). At most sections, the median grain size is smaller at the shoreline than that in the $1-\mathrm{m}$ water depth. At the east side of the sand spit, relatively smaller grain sizes are distributed. Figure 7 shows the composition of the sediment at each profile. The percentage of the sand was about $50 \%$ at Section A, and Section B has more than $80 \%$. At Section $\mathrm{C}$, the sediment at the tip of the sand spit contains larger grain sizes. The sediment size distribution appears to be related to the erosion and deposition pattern along the spit

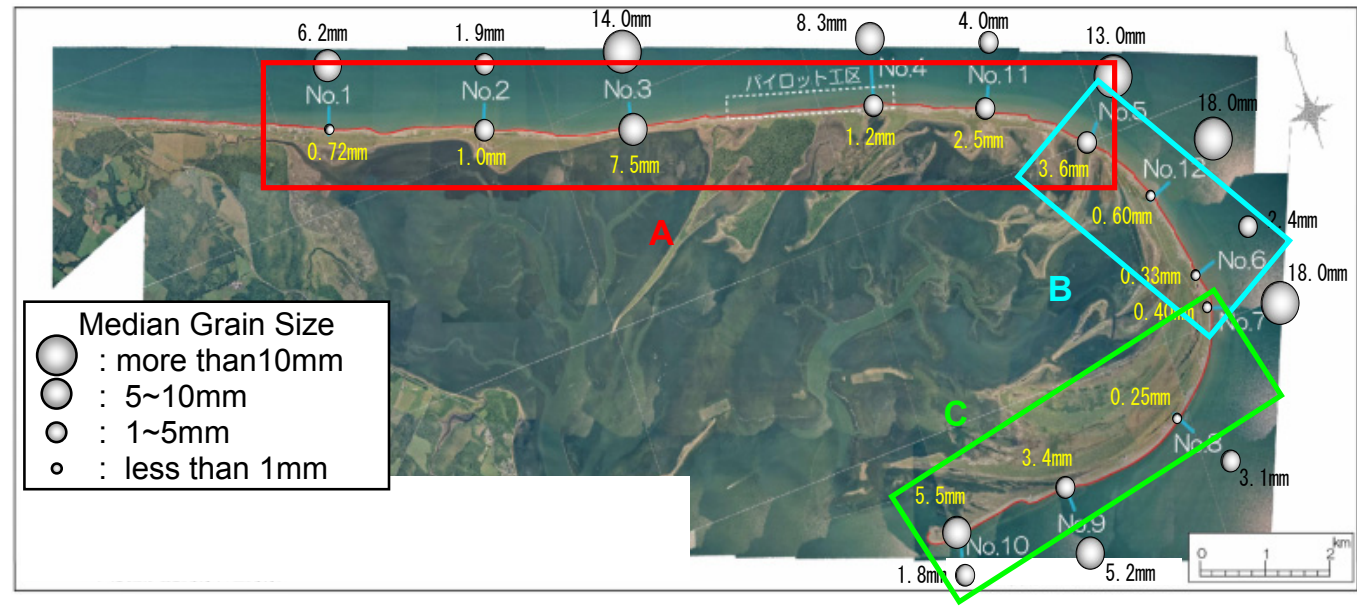

Figure 6. Location of sediment sampling survey and the median grain size.

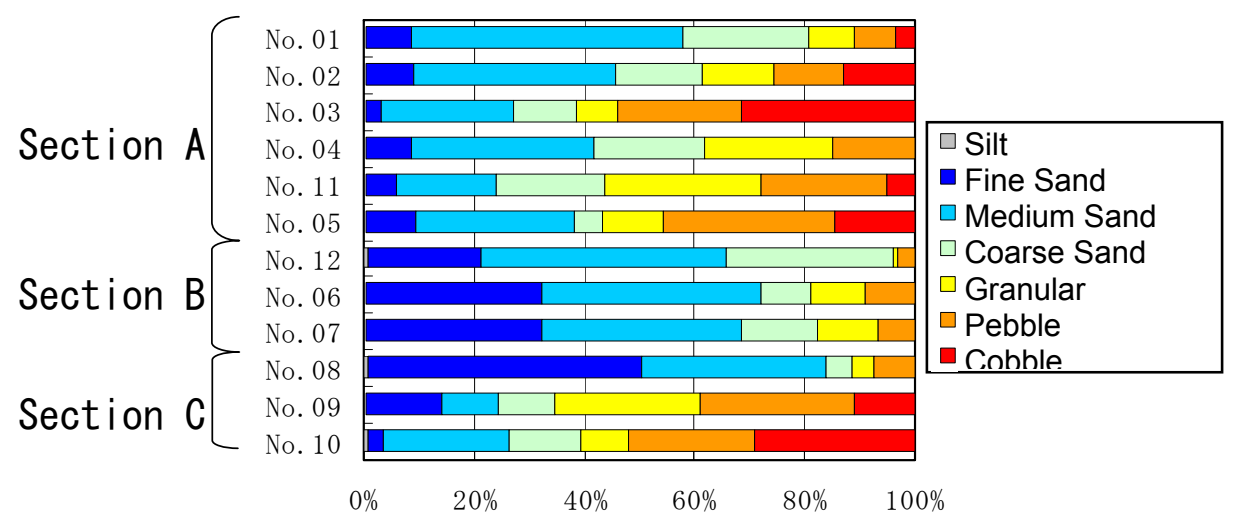

Figure 7. Sediment Composition at shoreline for each profile.

\section{Morphological Changes}

\section{Shoreline Evolution}

Uda et al. (1994) reported that the north side of the Shibestu fishing port in Figure 1 accumulated and the south side eroded gradually due to the reduced sand supply from the Shibetsu River and by trapping the southward longshore sediment transport by the fishing port. To understand the long-term shoreline evolution, the shoreline change is calculated using 3 aerial photos in 1947, 1999 and 2007. Figure 8 shows the shoreline changes during these periods where the Minehama fishing port is located further north in Figure 1. During 1947 to 1999, the left (northwest) side of the ports greatly advanced offshore, while the right (southeast) side obviously retreated. The spit eroded at Section A and B. The maximum erosion was about 75m. During 1999 to 2007, the shoreline changed less than 20m along the 
coast. This could be the effect of the groins and beach nourishment. Erosion continued at segments of no protection.

As seen in the wave direction and shoreline evolution, the dominant direction of the littoral drift is to the right (southeast). The head of the spit accreted during 1947 to 2007 as shown in Figure 8.

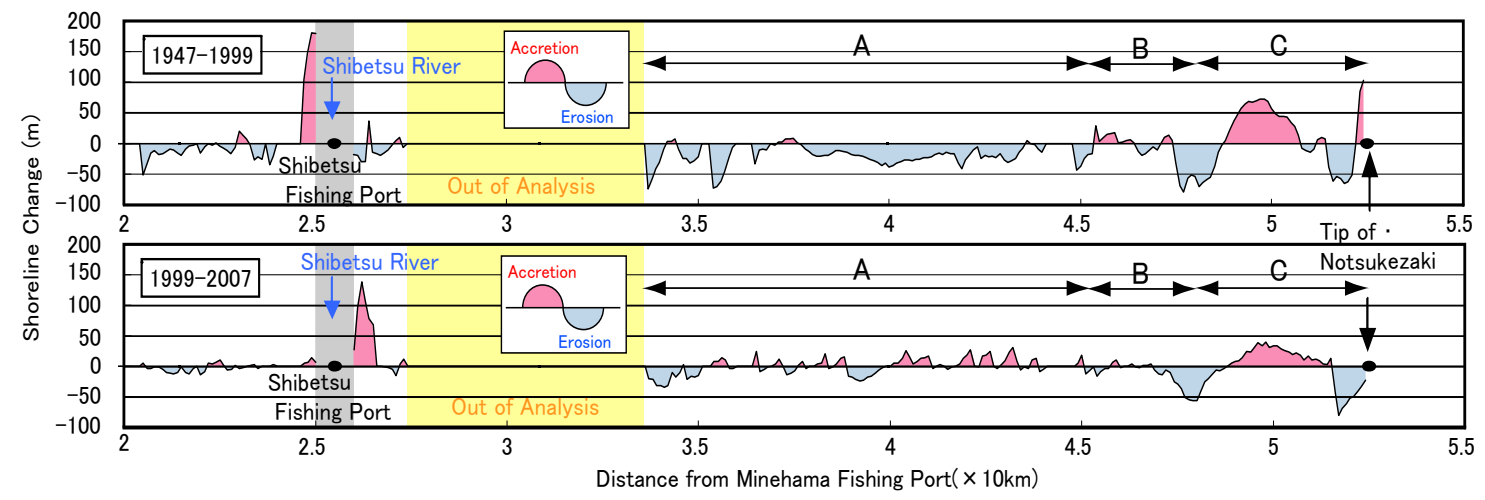

Figure 8. Shoreline change.

\section{Cross-shore Profile Evolution}

Since 1992, we have conducted the bathymetric surveys at the representative 12 profiles several times as shown in Figure 5. The beach profile evolutions at No. 1, 5 and 7 are shown in Figures 9, 10 and 11. In order to differentiate the topographic characteristics, the coast is divided into 3 sections; A, $\mathrm{B}$, and $\mathrm{C}$. In sections A and B, many groins had been constructed and then the updrift side of the groin has experienced accretion trend above $5 \mathrm{~m}$-depths. On the other hand, the downdrift side of groin has suffered erosion trend. In section $\mathrm{C}$, the profiles have experienced slight accretion trend. At the tip of sand spit, the beach profile changed greatly and a bar has been formed in $4 \mathrm{~m}$-depth and the sand on the top of the spit moved landward due to a certain storm. In summary, the topographic change has the different trend along the coast. The dominant sediment transport direction is longshore in Section A and B but is cross-shore in Section C.

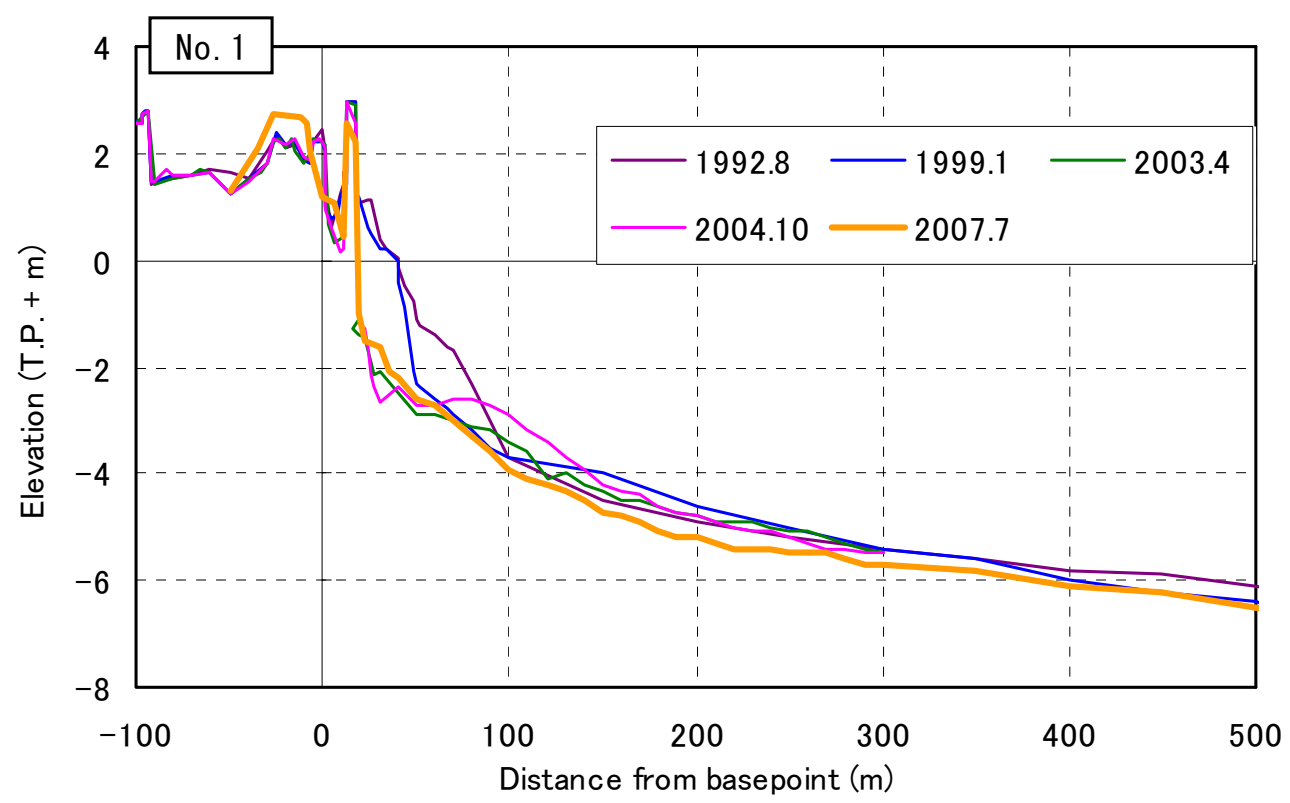

Figure 9. Beach profiles at No.1. 


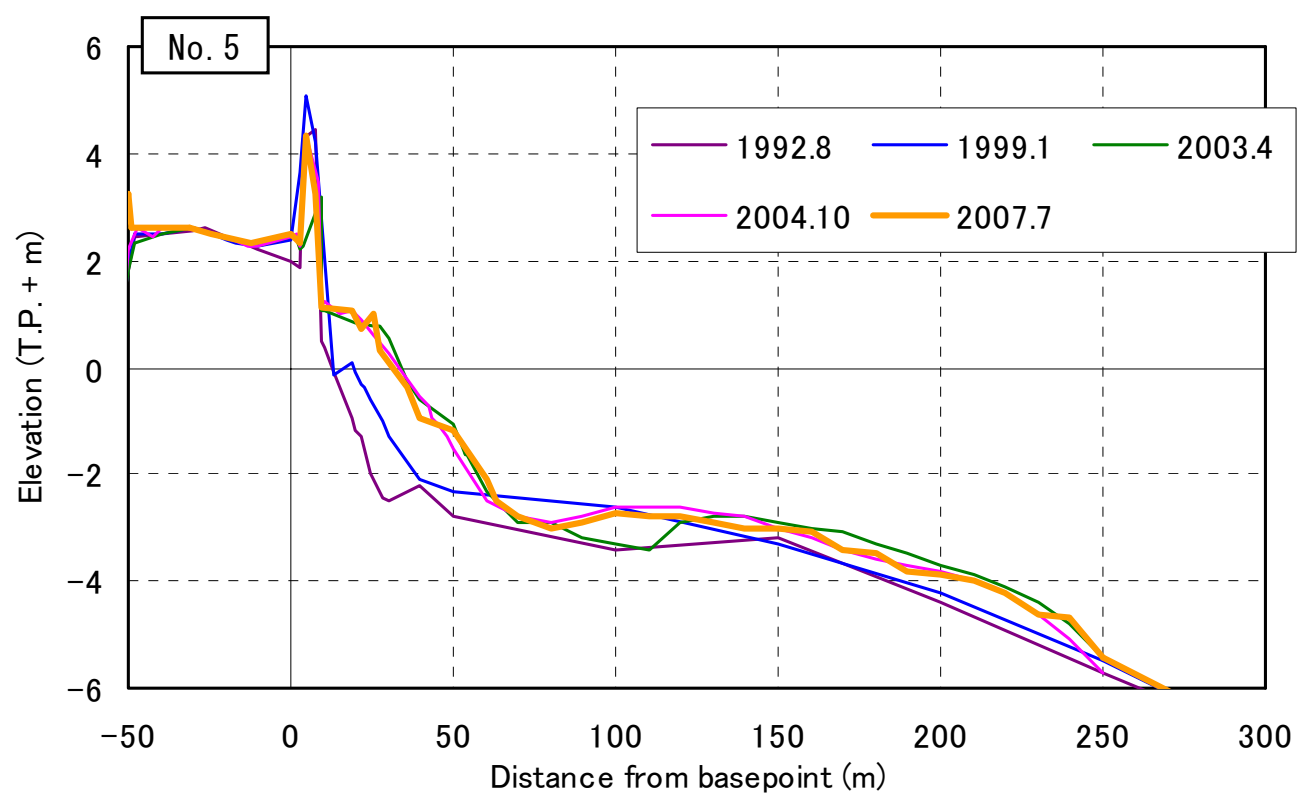

Figure 10. Beach profiles at No.5.

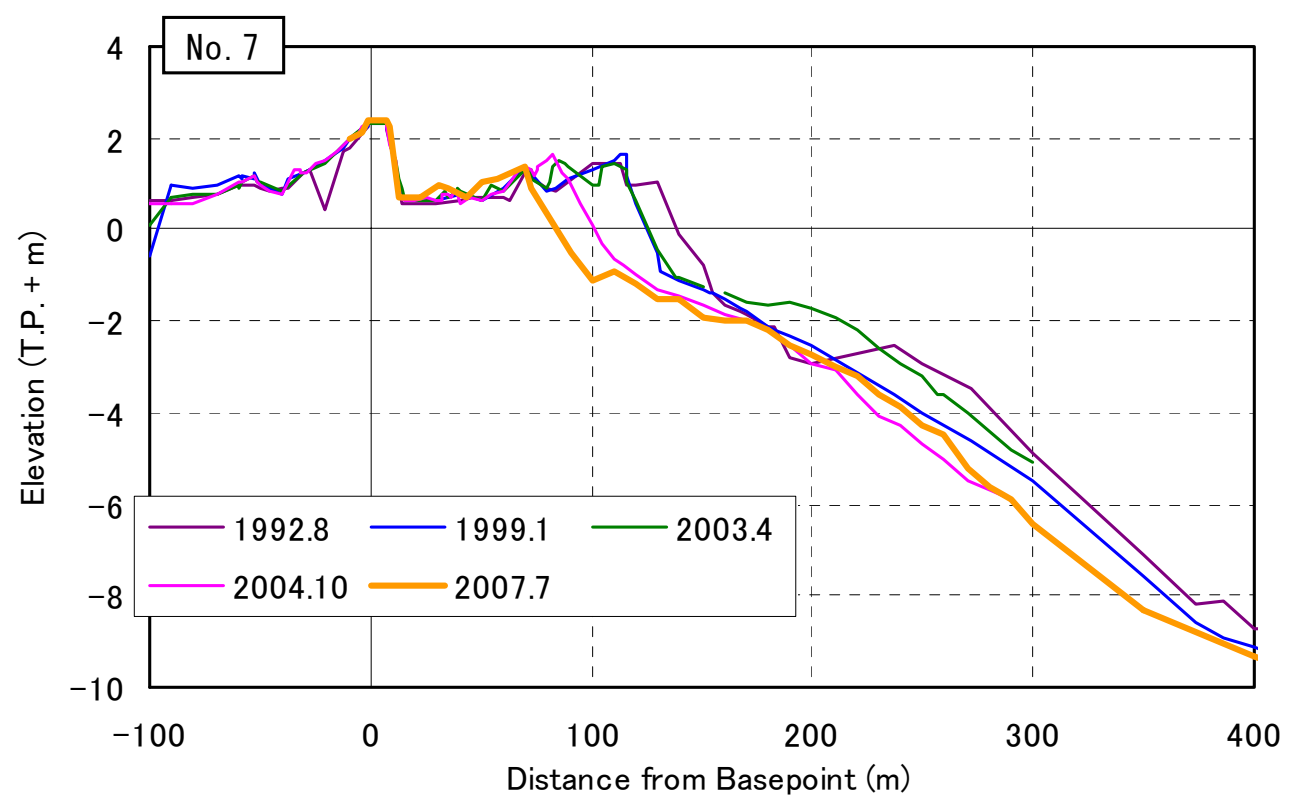

Figure 11. Beach profiles at No.7.

\section{Regional Sediment Budget}

The sand budget at a regional scale along the coast is investigated to understand the longshore sediment movement. Unfortunately, the long-term wave observation data has not been obtained near this site. In this study, the 5-year wave data (2003-2007) is estimated by wave hindcasting with a third generation ocean wave prediction model (WAM), which was extended to shallow water. This simulation is based on the atmospheric pressure and typhoon data provided by Japan Metrological Agency. The hindcast waves were in good agreement with the observed data in winter 2003 shown in Figure 2. 
Using the hindcasted wave data, the longshore sediment transport (LST) rates at representative 16 points are estimated using the CERC equation (USACE, 1984). The sand volume at each section between the two LST points is estimated using the shoreline displacement and the height of the profile landward of the closure depth. Moreover, as additional sinks and sources, the estimated sand volumes from the rivers, the dredged sand volumes at the ports and the beach nourishment volumes are considered in this sediment budget. Figure 12 describes the estimated sediment budget along the coast. As a whole, the direction of the longshore sediment transport is southeast. The estimated transport rate appears reasonable and decreases toward the tip of the Notsukezaki sand spit.
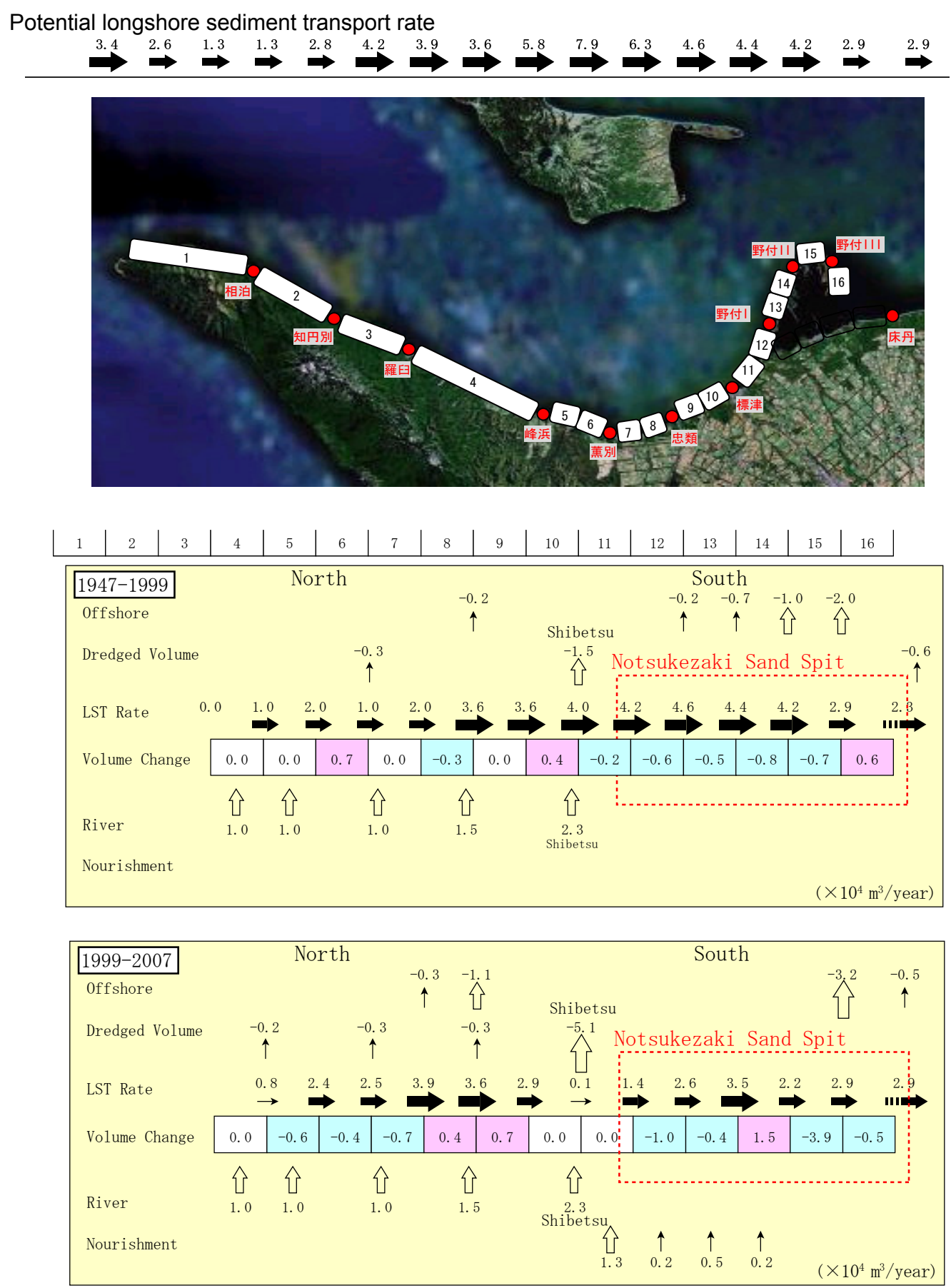

Figure 12. Regional sediment budget at Notsukezaki Sand Spit. 


\section{Numerical Simulation}

\section{Motivation and Methodology}

The wave characteristics vary along the sand spit as discussed in relation to Figure 2. As a result, the characteristics of the beach morphology vary with the wave characteristics. The coastal protection and beach management should be planned according to such characteristics. Recently, the erosion trend at Section C (Figure 7) has become severer and the coastal protection at Section C has become urgent. At Section C, the effect of bar formation and wave overtopping is investigated by several bathymetric surveys. The cross-sectional beach profile change is dominant rather than the longshore profile variation. In this study, a numerical simulation is performed for the cross-shore beach profile change at Section $\mathrm{C}$ in order to predict the beach profile change with and without protection measures and to evaluate the effectiveness of such measures.

The numerical model CSHORE has been developed by Kobayashi et al. (2008, 2010). This model consists of the following components: a combined wave and current model based on time-averaged continuity, cross-shore and longshore momentum, wave action, and roller energy equations; a sediment transport model for suspended sand and bedload; a permeable layer model to account for porous flow and energy dissipation; and a probabilistic model for an intermittently wet and dry zone for the purpose of predicting wave overwash and structural damage progression. This model has been calibrated and verified using a large number of small-scale laboratory experiments. Furthermore, this model has been calibrated using laboratory overwash tests and field profiles.

In this study, the input parameters are specified within the previous calibrations. Table 2 summarizes the input used in this simulation.

\begin{tabular}{|c|c|}
\hline \multicolumn{2}{|c|}{ Table 2. Input parameters. } \\
\hline Suspended load parameter & 0.2 \\
\hline Bedload parameter & 0.002 \\
\hline Overtopping parameter & $1.3-1.8$ \\
\hline Breaker ratio & 0.8 \\
\hline Runup wire height (m) & 0.05 \\
\hline
\end{tabular}
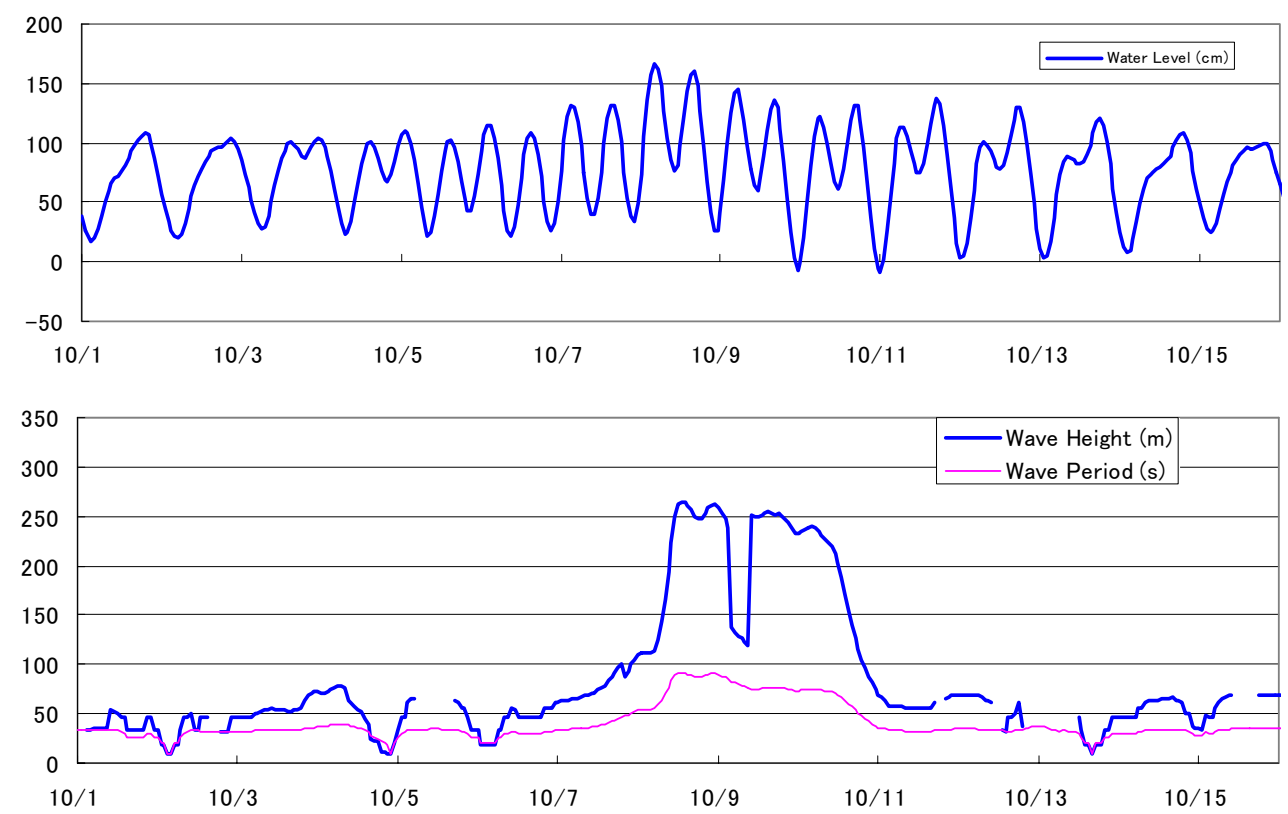

Figure 13. Estimated water level and wave conditions. 


\section{Simulation Conditions}

The offshore forcing for this simulation is the time-series of waves and water level. Unfortunately, there is no long-term wave and water level observation near this site. In this study, these offshore conditions are estimated for a severe storm which occurred in 2006. The simulation duration is 15 days in October 2006. The wave conditions estimated in the wave hindcast simulation are utilized. On the other hand, the water level is estimated using the tide table of the neighboring port, Nemuro Port. However, the water level should include the effects of air pressure and wind. The air pressure effect is simply included by calculating the water level difference due to the air pressure difference. Since the bathymetry is complicated, it is difficult to estimate wind effect on the water level easily and the wind effect is neglected in this simulation. Figure 13 shows the input wave and water level conditions. The estimated maximum significant wave height is $2.6 \mathrm{~m}$ and the wave period is $9.2 \mathrm{sec}$. The estimated maximum water level is $1.66 \mathrm{~m}$ above the datum.

Profile No.7 has a vegetation area behind the dune. Therefore, the friction factor $f_{b}$ varied from 0.002 to 0.2 for the vegetated area where $f_{b}=0.002$ for the non-vegetated areas. The sediment characteristics are summarizes in Table 3. The present CSHORE is limited to uniform sediment only and the spatial variation of the sediment characteristics (Figure 6) is not taken into account.

\begin{tabular}{|c|c|}
\hline \multicolumn{2}{|c|}{ Table 3.Sediment Conditions. } \\
\hline Median grain size $(\mathrm{mm})$ & 0.4 \\
\hline Fall Speed $(\mathrm{m} / \mathrm{s})$ & 0.07 \\
\hline Sediment density $\left(\mathrm{kg} / \mathrm{cm}^{3}\right)$ & 2.67 \\
\hline
\end{tabular}

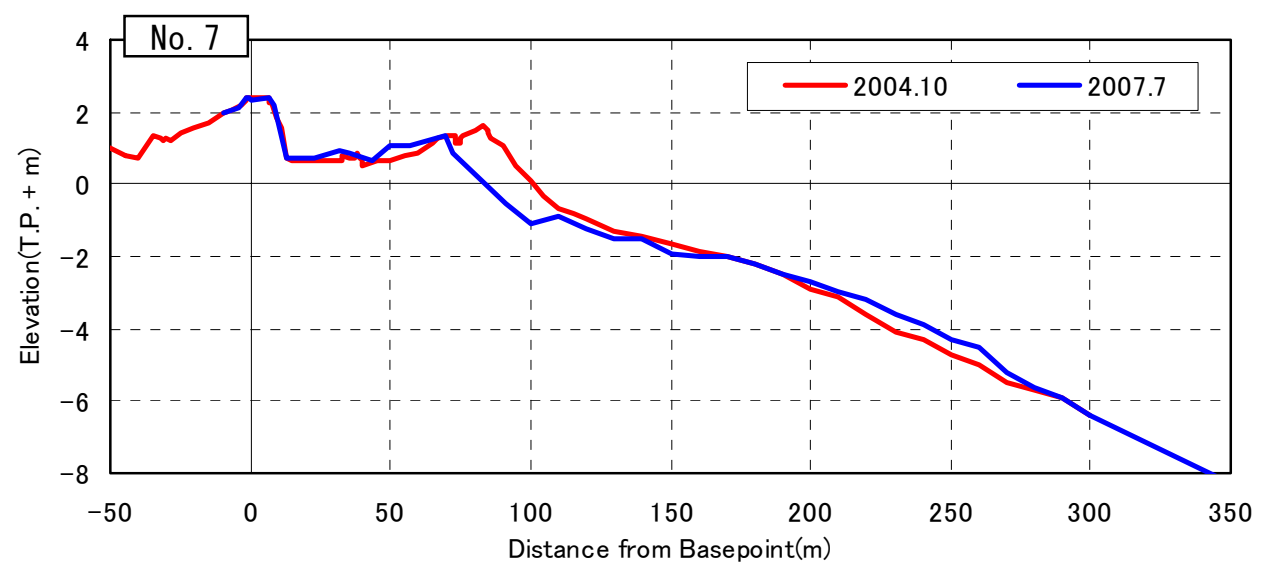

Figure 14. Beach profiles at No.7.

\section{Simulated Results}

Figure 15 shows the comparison of the simulated beach profiles and measured profiles. The dash line is the initial beach profile, which was observed at No.7 in 2004, and the solid and wide line is the measured beach profile in 2007 (see Figure 14). The simulated beach profiles are based on three different bottom friction factors for $f_{b}=0.002,0.02$, and 0.2 for the vegetation area.

The simulated profiles are in good agreement with the measured profile below $1 \mathrm{~m}$ depth. However, erosion near the shoreline was underpredicted perhaps because of alongshore sediment loss. This simulation focuses on the overwash mechanism on the vegetated dune during the severe storm. The entire duration (October 2004 - July 2007) between the two profile surveys is not simulated. 


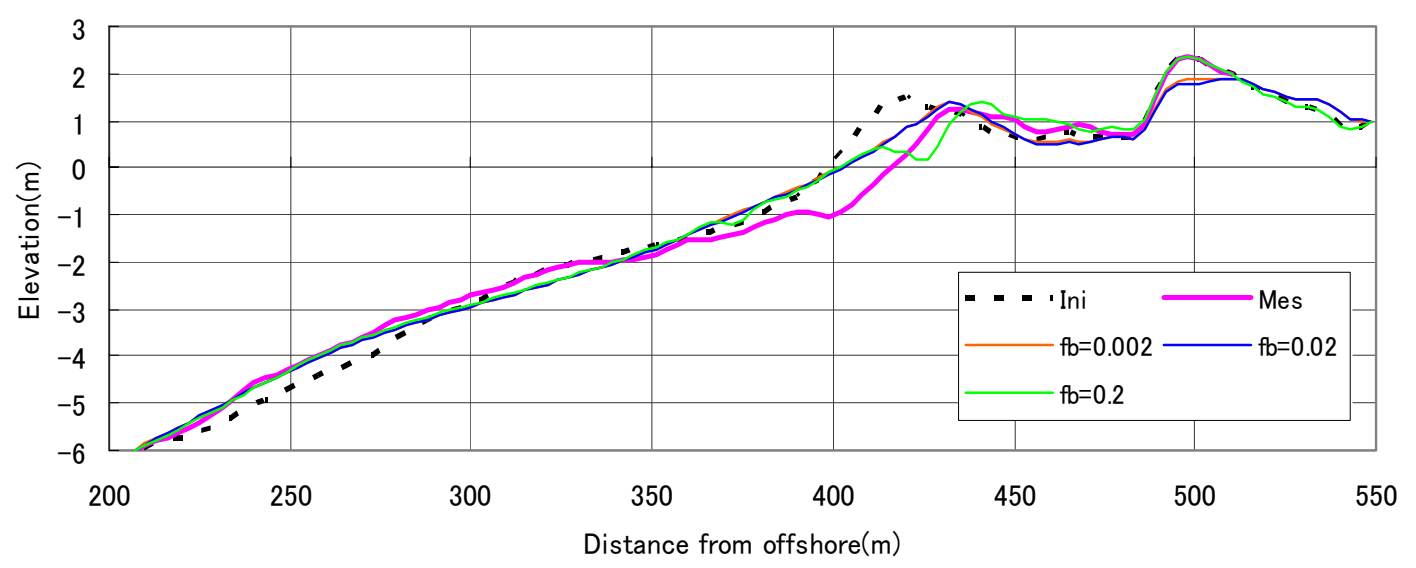

Figure 15. Comparison between simulated and measured profiles.

The bottom friction factor for the vegetated area influences wave overwash. For $\mathrm{f}_{\mathrm{b}}=0.002$ and 0.02 , the dune is overwashed and the dune crest is lowered. However, for $f_{b}=0.2$ no dune overwash occurred, as was the case with the measured profile.

In order to validate the model calibration, the Brier Skill Score (BSS) is applied in this study. The formula for the morphology is expressed by

$$
B S S=1-\frac{\left(\left|z_{b, c}-z_{b, m}\right|-\Delta z_{b, m}\right)^{2}}{\left(z_{b, 0}-z_{b, m}\right)^{2}}
$$

in which $z_{b}=$ bed level, $\Delta z_{b, m}=$ error of measured bed level, and $z_{b, 0}=$ initial bed level. Van Rijn et al. (2000) suggested the measured bed level error of $0.1 \mathrm{~m}$ in field conditions.

The BSS for the wave height, longshore velocity, cross-shore velocity and morphology was summarized by Van Rijn et al. (2003). The perfect agreement gives a Brier score of 1, whereas modeling the initial condition gives a score of 0 . Table 4 summarizes the BSS for the three different values of $f_{b}$. The vegetated area characterized by the significant increase of the bottom friction is important for the simulation of overwash of vegetated dunes.

\begin{tabular}{|c|c|}
\hline \multicolumn{2}{|c|}{ Table 4.BSS result. } \\
\hline $\mathrm{fb}=0.002$ & 0.29 \\
\hline $\mathrm{fb}=0.02$ & 0.29 \\
\hline $\mathrm{fb}=0.2$ & 0.43 \\
\hline
\end{tabular}

\section{Conclusions and Future Works}

The long curved sand spit is exposed to different wave conditions along its entire length. Groins may be effective in reducing beach erosion of the sand spit because of the dominant longshore sediment transport direction. Beach nourishment may be necessary after the groin construction. Sediment budgets are useful for the sediment movement assessment and management. CSHORE reproduces the measured profile reasonably; however the entire duration between the surveys will need to be simulated.

\section{ACKNOWLEDGMENTS}

We would like to express appreciation to the cooperation and efforts of Hokkaido Prefecture, Japan for providing the bathymetric survey data, observation data and aerial photographs used in this study. 


\section{REFERENCES}

Johnson, D.W. 1919. Shore Processes and Shoreline Development, Wiley, New York, 584p. [Facsimile edition: Hafner, New York (1965)]

King, C.A.M. and McCullagh. M.J. 1971. A Simulation Model of A Complex Recurved Spit, Journal of Geology, Vol.79, pp.22-37

Kobayashi, N., A. Payo, and L. Schmied. 2008. Cross-shore Suspended Sand and Bed Load Transport on Beaches. Journal of Geophysical Research, 113, C07001, doi: 10.1029/ 2007JC004203.

Kobayashi, N., A. Farhadzadeh, and J.A. Melby. 2010. Wave Overtopping and Damage Progression of Stone Armor Layer. J. Waterway, Port, Coastal and Ocean Eng., 136(5), 257-265.

Uda, T. and K. Yamamoto. 1992. Formative Process of Notsukezaki Compound Spit in Hokkaido, Transactions of Japanese Geomorphological Union, Vol.13, pp.17-33. (in Japanese)

Uda, T., and A. Kawamori, and T. Wakabayashi. 1994. Coastal Erosion and Coastal Protection at Notsuzaki Coast in Hokkaido, Proceedings of Coastal Engineering, JSCE, Vol.41, pp.521-525. (in Japanese)

USACE. 1984. Shore Protection Manual, U.S. Army Corps of Engineers, Washington DC 20314.

Van Rijn, L.C., B.G. Ruessink, J.P.M. Mulder. 2002. Coast3D-Egmond; the Behavior of a Straight Sandy Coast on the Time Scale of Storms and Seasons, Aqua Publications, The Netherlands.

Van Rijn, L.C., D.J.R. Walstra, B.Grasmeijer, J. Sutherland, S. Pan, and J.P Sierra. 2003. The Predictability of Cross-shore Bed Evolution of Sandy Beaches at the Time Scale of Storms and Seasons using Process-based Profile Models, Coastal Engineering, 47, 295-327. 